[慗化 第 48 巻, 第 6 号, p. $343 \sim 349,1974]$

\title{
定 $\mathrm{pH}$ 培養による Streptococcus cremoris の菌体収量につ々て*
}

\author{
入江良三郎, 岡本隆史, 森地敏樹 \\ (農林省畜産試験場) \\ 昭和 48 年 11 月 14 日受理
}

\begin{abstract}
Growth Yield of Streptococcus cremoris Cultivated at Controlled $\mathrm{pH}$
By Ryozaburo IRIE, Takashi OKAMOTO and Toshiki MORICHI

National Institute of Animal Industry, Aoba-cho, Chiba-shi
\end{abstract}

\begin{abstract}
A simple system for laboratory cultivation of lactic acid bacteria at automatically controlled $\mathrm{pH}$ has been described. A strain of Streptococcus cremoris was grown at $30^{\circ} \mathrm{C}$ in a $300 \mathrm{ml}$ quantity of culture medium containing $2 \%$ tryptone, $1 \%$ yeast extract, $5 \%$ lactose and $0.2 \% \mathrm{NaCl}$. The $\mathrm{pH}$ of the culture was held at $6.0 \sim 6.2$ using $\mathrm{NH}_{4} \mathrm{OH}$ as a neutralizer, which, in accordance with Peebles et al., ${ }^{(4)}$ proved superior to $\mathrm{NaOH}$ or $\mathrm{KOH}$.

It was noted that the main part of the growth curve was linear against culture period (an arithmetic linear growth).

The maximum growth yield of $4.2 \mathrm{mg}$ dry wt. $/ \mathrm{ml}$ (viable count, $3.7 \times 10^{9} / \mathrm{ml}$ ) was attained after about 12 hours, whereas the alkali consumption continued until the sugar was exhausted. The acid produced was mainly $L(+)$-lactate.

The overall $Y_{\text {AtP }}$ (grams cells formed/mole ATP formed) was about 9 , as calculated on an assumption that one mole of ATP was formed per one mole of alkali consumed. However, higher $Y_{\text {ATP }}$ value of about 15 was found in the earlier part of the growth. Some physiological and practical implications of these results were discussed.
\end{abstract}

(Received November 14, 1973)

凍結乾燥スターターや，凍結濃厚スターターを製造す る場合に，技術的に問題となる点のひとつは，大量の乳 酸菌菌体を簡易に，息た安価に得ることである。

乳酸菌は，自分が生産する乳酸によって培地の $\mathrm{pH}$ を 下げ，多くの場合これが制限因子になって，增殖が止っ てしまう、したがって，培地を絶えず中和して $\mathrm{pH}$ 定保保ってやれぱ，增殖が良くなることが期待される．

このような培盖法は，実驞室的には古くから試みられて 物り (1)，最近では凍結濃厚スターター製造のための定 $\mathrm{pH}$ 培養の研究が，さかえに行なるれている(2).

私達も，実用的な定 $\mathrm{pH}$ 培養の基礎資料を得，市わせ て乳酸菌の増殖や生酸活性飞関する生理学的な問題点を 明らかにするために，実験を開始した。

\section{実験材料および方法}

1. 菌株当研究室で分離；保存している Strepto* 乳酸菌の定 $\mathrm{pH}$ 培養(第1 報). coccus cremoris $\mathrm{H}-61^{(3)}$ を使用した。

2. 培地 トリプトン (Difco) $2 \%$ ，醉母エス （Difco） $1 \%$ ，食塩 0: $2 \%$ ，乳精 $5 \%$ のものを使用した。 乳糖は，別江高王滅菌し，使用直前化加光た。な报，こ の培地組成は, Peebles ら ${ }^{(4)}$ Kよって，濃厚スターター の培養に用いられたのと類似のものである.

3. 前培養 リトマスミルク培養から，上記の培地 $30 \mathrm{ml}$ K 1 滴接種し, $30^{\circ} \mathrm{C}$ で 16 時間静置培荃したも の(生菌数 $4 \times 10^{8} \mathrm{cell} / \mathrm{s} / \mathrm{ml}$ ) を前培羡とした。

4. 接種と培䖯 上記の前培養の全量を, 培地 270 $\mathrm{ml}$ (総量 $300 \mathrm{ml}$ ) 飞加兄, アルミはくで覆った $600 \mathrm{ml}$ 容のビーカー中で，マグネテックスターラーで㹂拌しな

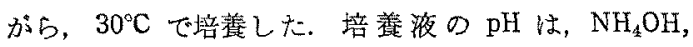
$\mathrm{NaOH}$ または $\mathrm{KOH}$ (いずれす約 $3 \mathrm{~N}$ )で，6.0 に保っ た.

5. pH スタット 手持ちの $\mathrm{pH}$ メータ（日立一堀 場，H-5 型）と，微量送液ポンプ(“ペリスタ・ミニポ 


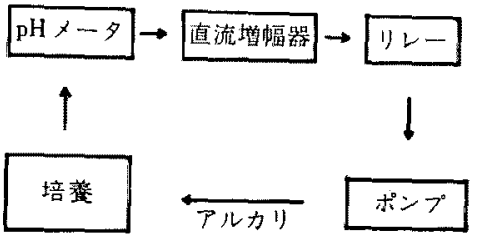

第 1 图 $\mathrm{pH}$ スタットの鿰成

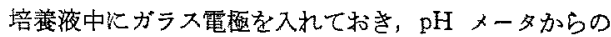
信号を增幅してりレーを゙動加し，アルカリ供給用のポソプ 完制御する。

ンプ”ミシミSJ-1210 型)を利用し，これ火自作の直 流增幅器とリレー回路を加支て, 第1図の上5に構成し た.すなわち，培地中にガラス電極（複合型）をそう入 して我き， $\mathrm{pH} メ ー タ か ら ， \mathrm{pH} 7$ からのずれに比例した 信号をとり出し，これを增幅しでリレーを動かし，これ でポンプを動かしてアルカリを培地に加えるようにし

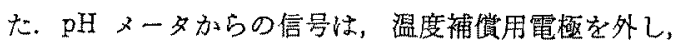
この電極用の端子がらとり出した（温度補償用電極は， $\mathrm{pH}$ を直示するメ一タと並列に入って括り，温度によっ てその抵抗が変ることを利用して，温度補償を行なって いる、したがって、ここには $1 \mathrm{pH}$ あたり $20 \mathrm{mV}$ 程度 の值流電壬が方らわれる)。な拈，培皘温度に拈ける温 度補償用電極の抵抗 $\left(30^{\circ} \mathrm{C}\right.$ で約 $\left.9 \mathrm{k} \Omega\right)$ と, 直流增幅器 の入力抵抗との差による $\mathrm{pH}$ 指示値の望差（奏際にはそ れほど大きくなく， $\mathrm{pH}=6$ 付近で 0.01 程度）を防ぐた め, 7 合わせと 4 合わせは, 直流増幅器とりレ一駆動回 路を、すへててットした状態で行なった。

直流増幅器とりレー駆動回路は，ごく簢単なもので， 回路図は第 2 図のと括りである。直流增幅器(第 2 図a)
の可変抵抗 Vol. $1(50 \Omega)$ は, 零点調整用 $(\mathrm{pH} メ ー タ$ の指示が7のとき，出力がゼ口になるようにする)， Vol. $2(2 \mathrm{k} \Omega)$ は，ハイアス調整用（pH メータの指示を 7 から少しずらし，出力が最大になるよらに調整であ る. 電源は, 乾電湖（単 3,2 本）を使用した。直流增 幅器の出力を, リレー駆動回路の入力として使用した。 リレ一駆動回路（策 2 図b) の可变抵抗 $(250 \mathrm{k} \Omega)$ を回 して，希望の $\mathrm{pH}(6.7 \sim 5.6$ の範国で可変) でリレーが onするよらに調整した，電源は，交流を整流，平滑化 して用いた。りレーの接点で，ポンプのりモート端子 (メインスイッチを 的にしたをまで，リモート端子を 開放すれば動き，短絡すれば止る）を開閉し，ポンブを 制御した.

アルカリ液は，メスシリンダーに入れて执き，目盛か らアルカリ消費量を読みとった.

なおこの図には示していないが，奏際にはこのりレ 一で，第 2 リレー（オムロン MK-2）駆動し，その 2つの接点を使って，ポンプの制御と、アルカリ消費量 の自記記録（ポンプが動いている時間に比例した高さの ピータが，記録紙上に現われるよらに工夫）を行なわせ ている。

な特，培垷に使用したビーカー(テフロン被覆した㭡 找子を入れ，テルミはくで琵って蛙く，メスシリンダ 一、アルカリ用シリコンゴム管（内径 $1 \mathrm{~mm}$ ) は，すへ て事前に高王隇菌した，ガラス電極は，アルコールで拭 いたのち隇菌水で洗い，フルミはくに小穴をあけて，ビ 一カー中にそら入した。

6. 分析 生菌数は食塩水で希釈後, トリプメ

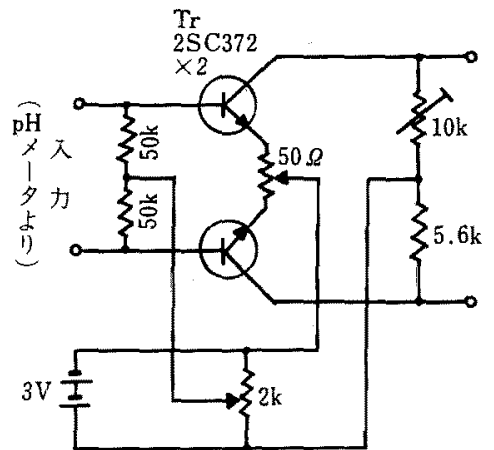

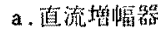

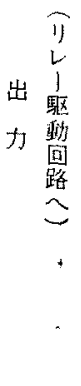

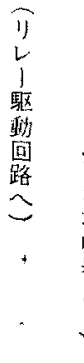

第2図 值流増幅器と，リレー駆動回路の回路图

a.エピタキシャル・プレーナ形シリコントランジスタ 2 個に上る留単な差動式增幅器.

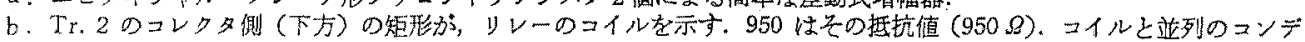
ンサ $(100 \mu \mathrm{F})$ は, りレーの接点の振動防止用. 


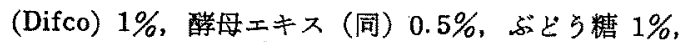
食塩 $0.2 \%$ ，粉末寒天 $1.5 \%,{ }^{\prime} \mathrm{pH} 6.8$ の培地で, $30^{\circ} \mathrm{C}$, 2 日間平板培養したのち計測した。

乾燥菌体量は，培養液 $10 \mathrm{ml}$ をスピッッグラスにと って遗心し, 同量の蒸留水で 3 回遠心洗浮後, $100^{\circ} \mathrm{C} て ゙$ 恒量になるまで乾燥，科量して求めた。乾燥菌体量と 0.D. (10〜30 倍に希秎後, イトー・クレット光電比色 計で，660 m $\mu$ のフィルターを用いて測定）の関係を求 めておき，培養の時間経過をみるときは，O.D.から乾 燥菌体量を算出した。乾燥菌体量と O.D. の関係は, 種々の時期の培着を用いて、くり遮しチェックした。

乳酸は，乳酸脱水素醉素を用いて湘定した ${ }^{(5)}$.

乳糖は、ソモジ・ネルソン法(6)によって測定したが, 培地がペプトン等を含むため, 测定値が不正確なので, 糖を全部消費したか否かの目安とする程度に止めた。

\section{実 験 結 果}

\section{1. 培荃释過}

培地の $\mathrm{pH}$ は，培息開始洔は 6.4 付近であっだが，2 時間前後で6.0 亿達した. 以後, $\mathrm{pH}$ は 6.0〜6.2 亿保た

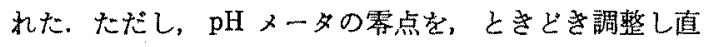
す必要があり，これを行なわないと，最高で 0.2 程度の 誤差を生しることがあった。直流增幅器とリレ一駆動回 路は，一度調整しておけば，少なくとす 24 時間は安定 で再調整の必要はなかった。

酸の生成（アルカリの消費）と, 菌の增殖の時間経過 の一例（中和剂は $\mathrm{NH}_{4} \mathrm{OH}$ ) を, 第 3 园aに示す、アル カリ消費量る菌体量も，培湌ビーカー中の全内容物につ いての值である。酸生成量と畭燥菌体量とは，ほ注並行 しているが，堌殖曲線の主要部分が，時間に対して直線 的であること(したがって，この部分の比增殖率一一図 中の点線——，急速に低下している)，菌体量が頭打 ちになってからも, 酸生成がしばらく続いていることか゚ 特徵的である.な柿，比増殖率从の定義は，つぎのとお りである。

$$
\mu=\frac{1}{M} \cdot \frac{d M}{d t}
$$

ただし，Mは菌体量， $t$ は培養時間である（実際に は,たとえば $t=6$ 時間から $t=7$ 時間までの間の菌体 量の增加分を, $t=6.5$ 時間の点の菌体量で除したもの を $t=6.5$ 時間に乱を当とした).

酸生成が停止した時点では，楉意は添完全に消費して

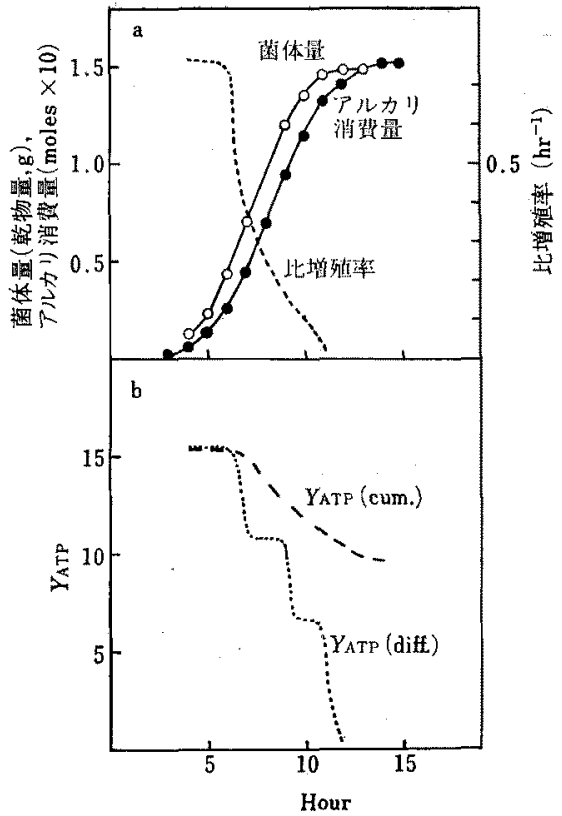

第 3 图 $\mathrm{NH}_{4} \mathrm{OH}$ を中和剤としたときの培養趶過

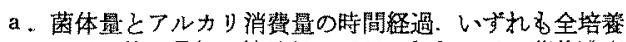
液についての值. 最初の培地量は $300 \mathrm{ml}$ なので, 菌体濃度 を $m$ (乾物量 $\mathrm{mg} / \mathrm{ml})$ ，アルカリ夜の消费量を $l(\mathrm{ml})$ ，そ

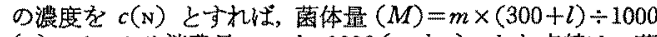
(g),アルカリ消費量 $=c \times l \div 1000$ (moles). なお点楾は, 菌 体量の曲線から計算した比增殖率 $(1 / M \cdot d M / d t)$.

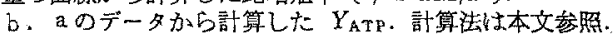

おり，ホモ乳酸発こう(乳糖 1 分子から，乳酸 4 分子が 生成）としてアルカリ消費量から計算すると，消費糖の 約 90\%が乳酸になった勘定になる。こうして計算した 乳酸量性，乳酸脱水素酵素炕よって定量した值上，注ば 一致した（たとえば第 3 図の例では，アルカリ消費量 $152 \mathrm{mM}$ に対し，乳酸脱水素酵素による乳酸量は 160 $\mathrm{mM})$.

增殖停止時の菌体濃度は, この場合, 乾燥菌体量で約 $4.2 \mathrm{mg} / \mathrm{ml}$, 生菌数で $3.7 \times 10^{9} / \mathrm{ml}$ であり,この值は同 し培地で中和せずに培盖した場合の 7 10 倍に当る。す た，生菌数は，脱脂乳培養の場合の約 7 倍である。

\section{2. 中和剤の種類}

中和剤の種類を変えた場合の結果は第1表のとおりで ある。乾燥菌体量では，中和剤による差は方秀り䫒著で ないが，生菌数でみると， $\mathrm{NH}_{4} \mathrm{OH}$ が断然すぐれている. これは; S. cremoris の定 $\mathrm{pH}$ 培盖で得られる生菌数に 対する中和刜. $\left(\mathrm{NaOH}\right.$ と $\left.\mathrm{NH}_{4} \mathrm{OH}\right)$ の結果をしらべホ Peebles ら ${ }^{(4)}$ の結果と一致している，KOH は，菌体がかたまって小さなペレットを作る傾向が市 
第 1 表 中和剂の種類の影䒠

\begin{tabular}{|c|c|c|}
\hline \multirow{2}{*}{ 中和剂の垂類 } & \multicolumn{2}{|c|}{ 最終の菌濃 度 } \\
\hline & $\begin{array}{c}\text { 乾燥菌体量 } \\
(\mathrm{mg} / \mathrm{ml})\end{array}$ & ${ }^{\text {生 }} \underset{\left(10^{9} / \mathrm{m} 1\right)^{\text {药 }}}{\text { 数 }}$ \\
\hline $\mathrm{NH}_{4} \mathrm{OH}$ & 4.2 & 3.7 \\
\hline $\mathrm{KOH}$ & 3.9 & 1.5 \\
\hline $\mathrm{NaOH}$ & 3.8 & 2.5 \\
\hline 中和せず & 0.5 & 0.4 \\
\hline 貺脂乳培羡 & - & 0.5 \\
\hline
\end{tabular}

三種類（いずれる約 $3 \mathrm{~N}$ ) の中和凪のうちのひとつを用い て，酸生成方停止するまで（いずれの場合名 $14 \sim 15$ 時間）

培羔し，乾燥菌体量 (O.D. Kよらず直接) と生菌数を測定

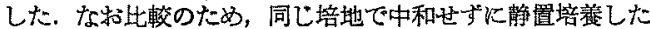
場合と，通常の脱脂乳培美の易合の值を示した。

りこれが生菌数が少なく出る原因のひとつと考えられ る $\left(\mathrm{NH}_{4} \mathrm{OH}\right.$ 中和の場合は，細胞の大部分は 4 個または 6 個の連鎖をなしている)，上記の Peebles ら(4)は， $\mathrm{NaOH}$ を用いた場合は，粘質物の生成が認められると述 ベている.

\section{3. $Y_{\mathrm{ATP}}$ による菌体収量の評価}

この培養法での菌体収量が，ほ注限界なのか，それと も大幅に改善の余地があるかを判断するには，Bauchop and Elsden(7) の提晿した $Y_{\text {ATP }}$ を用いると便利である。 彼らは，エネルギ一源として加克た基貿の代謝経路がわ かっている（すなわち，基質の消費量から ATP の生成 量を計算できる)ことを前提に， $Y_{\text {ATP }}$ をつきのように 定義した.

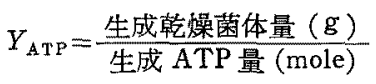

彼らは，菌株，基質，代謝経路のことなる多くのケ一 スで，エネルギー源が制限因子の場合， $Y_{\mathrm{ATP}}=8 \sim 12$ （平均 10.5）といら一般法則が成り立つとした。

ホモ乳酸発こう（Embden-Myerhof 経路経由）の場 合は, 乳酸が 1 分子生成するごとに, 正味 1 分子の ATP が生成することになるので，上の式はつぎのよら書き かえられる。

$$
Y_{\mathrm{ATP}}=\frac{\text { 生成徬燥菌体量 }(\mathrm{g})}{\text { 乳酸生成量 }(\mathrm{mole})}=\frac{\text { 生成乾燥菌体量 }(\mathrm{g})}{\text { アルカリ消費量 (mole) }}
$$

したがって，この場合の $Y_{\mathrm{ATP}}$ は，アルカり消費量と 菌体量から計算できる，計算に艻たっては，つぎの式を 用いた，すなわら，ある時間培差したときの菌体濃度を $m$ (乾物量 $\mathrm{mg} / \mathrm{ml}$ )，アルカリ液消費量（培羑開始時の 培地量 $300 \mathrm{ml}$ についての) を $l(\mathrm{ml})$, アルカリ濃度を $c(\mathrm{M})$ ，培盖開始時の菌体濃度を $m_{0}$ とすれば，

$$
Y_{\mathrm{ATP}}=\frac{m \times(300+l)-m_{0} \times 300}{c \times\left(l+l_{0}\right)}
$$

な牧 $l_{0}$ は，培差開始時から $\mathrm{pH}$ が 6.0 Kなるまでの 酸生成量（培地の $\mathrm{pH}$-滴定曲線から算出）を, 濃度 $c の$ アルカリ液の消贅量に換算したるのである（サンプリン グによる減量は，1回がたかだか $0.5 \mathrm{ml}$ 程度であるの で，無視して差支ない).

こうして計算した $Y_{\mathrm{ATP}}$ は，培養終了時（酸生成停止 時)で 9 前後であり, Bauchop and Elsden(7)のあげた 範囲内に入って持り，それほど悪い収量ではないとい党 る.

$Y_{\text {ATP }}$ を，培養時間の種々の時期に計算してみると， 第3図 b の長い点線のように，はじめは 15〜16 といら 高い值を示すが，次第に低下して，最後は 10 を割るよ らになる。この変化は一見単調であるが，見方をか克 $\tau$, 菌体の增加速度と酸の生成速度の比加ら，各時点に 和计る菌体の收率を計算すると，るっと明瞭な变化が期 待される。このよらな意味の $Y_{\text {ATP }}$ を, differential な 性格の $Y_{\mathrm{ATP}}$ といらことで $Y_{\mathrm{ATP}}$ (diff.) と呼び，さき に示したような $Y_{\text {ATP }} を$, cumulative な性格の $Y_{\text {ATP }}$ といら意味で， $Y_{\mathrm{ATP}}$ (cum.) と呼んで区別することにす れば， $Y_{\text {ATP }}$ (diff.) は次式によって計算される.

$$
Y_{\mathrm{ATP}}(\text { diff. })=\frac{(m+\Delta m)(300+l+\Delta l)-m \times(300+l)}{c \times \Delta l}
$$

ここで， $\Delta m$ 括よび $\Delta l$ は，菌体濃度执よびアルカリ 液消費量の，1時間当りの増加分である。

$Y_{\mathrm{ATP}}$ (diff.) は，第 3 図 bのこまかい点線のように， きわめて特徵的な推移を示す。すなわら、はじめは約 15 といら高いレベルを保つが，菌体量が時間に対して直線 的な増加に入るころ（比增殖率（ $\mu$ )の低下が㞒著になり 始めるころ）から一気に低下し，10１1 でブラトーを 作る、このプラトーは，菌体量，テルカリ消費量が，と もに道線的儿並行して增加している部分に刘応する。つ いで, 増殖速度の低下を反映して， $Y_{\mathrm{ATP}}$ (diff.) は急激 に娍少し，增殖が停止した点（アルカリの消費は，この 後もしばらく続く)で0になる.この間，6 付近に第 2 のプラトーが現かれるが，これは 10 付近のプラトー致 とは再現性がなく，やや㑯斜がゆるるなる程度のことる ある. 第 2 のブラトーは, 增殖速度の低下に続いて生酸 速度の低下が起こり，しばらくの間，兩者がほぼ同じ率 で低下を続けることの反映である。

培養初期の高い $Y_{\text {ATP }}$ が, 培地中の何か他のエネル 
ギー源の消費（たとえば，S. faecalis はアルギニンをエ ネルギー源として利用する(7,10) のではないかとる考えられたが，この菌株は乳糖を抜い た培地では，測定にかかるほどの生育を示さなかった。

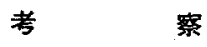

Peebles ら (4)は，ぶどら糖，乳糖各 $2.5 \%$ を炭素源と する培地で, 3 株の S. cremoris 杂培養 L, 培地の $\mathrm{pH}$ を $\mathrm{NH}_{4} \mathrm{OH}$ で 6.0 に保って，14 17.5 時間で $7.3 \times$ $10^{9} \sim 1.1 \times 10^{10} / \mathrm{ml}$ の生菌数を得た。彼らの菌株と，今 回用いた H-61 との間には，細胞の大きさや連鎖の長さ （本報の場合には，培養終了時に和いて 4 6 個の連鎖を なするのが多かった）などの違いもあると考えられるの で、かれらの結果と, 私達の $3.7 \times 10^{9} / \mathrm{ml}$ とを直接比輘 することはできない，彼らは，菌体量を記載していない ので，これについてる比較できないが，やはり生育停止 後しばらくの間，アルカリ消費が続いたと述べているこ とからみて， $Y_{\text {ATP }}$ が並外机て高かったとも考完にく く，今回の成績は，かれらに潘医敵するのではないか と考えられる.

糖の濃度が一定の培地で，菌の収量を上げようといら ことは， $Y_{\text {ATP }}$ を殀ようということと同等である.

Bauchop and Elsden ${ }^{(7)}$ 以来，工ネルギー源が菌体収 量の制限图子となる条件下で， $Y_{\mathrm{ATP}}$ が約 10 になるとい らことは，多くのケースについて確かめられてきた ${ }^{(8,9)}$. たまたまこれから外れるように見光る例も，代謝経路 が想定とらがっていたり，菌体への同化分を無視してい たりしていて，これ在補正すれば，多くの昜合は 10 付 近に落ちつくとされている(9).

しかし $Y_{\text {ATP }}$ が，10よりずっと大きくなるという例 も存在する ${ }^{(10,22)}$. たとえば, Moustafa and Collins ${ }^{(10)}$ は，S. diacetilactisなどのパッチ法および連続法による 培盖で， $Y_{\mathrm{ATP}}=17$ という高い值を報告している.この 場合，基質の濃度は低く（ふとう精の場合 $1 \sim 6 \mu \mathrm{M}$ ）, 高い $Y_{\text {ATP }}$ 值は，このような培盖の初期 (growth phase でいえば，必ずしも初期とはいえないが）に沏いて観察 されたことに注目する必要がある(9). 今回の結果で，培 荃の初期に $Y_{\mathrm{ATP}}=15$ という高い值が得られたことと 上記 Moustafa らの結果とは，関係か゚あるかもしれな W.

乳酸菌の代謝経路がさらにのびて，酷酸ができ，その さい余分の ATP がでさるので， $Y_{\text {ATP }}$ がみかけ上 10
より高くなるという可能性がある(18,20,21). 培荃初期の

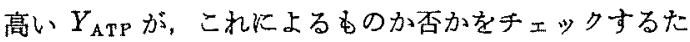
めに，低い糖裖度 $(0.4 \%)$ の培地で培盖し，アルカリ消 費の止った時点（ここまで $Y_{\mathrm{ATP}}=15.7$ ，糖消費量とア ルカリ消費量は一致)で，ガスクロマトグラフィーによ る揮発酸の分析を行なった，その結果，酢酸のピークが 認められたが，その量性総酸の $1 \%$ 以下であり， $Y_{\text {ATP }}$ の值に影響するほどではなかった。なお，酢酸以外のピ ークは認められなかった。

$Y_{\mathrm{ATP}}$ の理論的な上限は，菌体成分と，艺の合成に必 要な高エネルギーりん酸結合の数から計算した Gunsa-

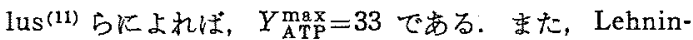
$\operatorname{ger}^{(12)}$ が, 大腸菌細胞 1 個の合成に必要としているATP の数から， $Y_{\mathrm{ATP}}$ の上限を計算すると， $Y_{\mathrm{ATP}}^{\mathrm{max}}=52$ とな 万.

これらの值は，能動輸送や代謝回転などに要与るエネ ルギーを慜視した，「最大限でも，これとは及ばない」 といら值である，しかし，Moustafa らの17や，今回 の培着初期にみられた 15 といら值は，これらの理諭的 上限よりるはるか低く，あってる特かしくない值とい える.

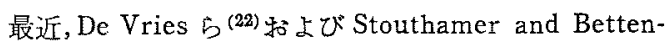
haussen ${ }^{(14)}$ は， $Y_{\text {ATP }}$ の問题を再検討し， $Y_{\text {ATP }}$ は決し て 10 付近に固定したものではなく，比増殖率の増大 にとるなって大きくなることを示した，かれらは，菌体 成分の合成以外に必要なエネルギーとして，菌体の維持 (maintenance) のためのエネルギーをあげ，比增殖率が 低い場合には，維持エネルギーの比重が相対的に增加す るために，Y $Y_{\mathrm{ATP}}$ の低下をま扑くとしている。

か礼らはまた，増殖とエネルギー代謝の関係は，ふつ らに信しられている以上に, 密接に関連して変化すると 繥論しているが(14)，培養条件をか克て上增殖率を急落 させた場合，単位菌体量当りの代謝速度の低下が，それ についていけず，一時的に，代謝と增殖の uncoupling (したか゚って， $Y_{\text {ATP }}$ の過度の急落一定常状態の回復 によってあるレベルまで回復される）がみられる例(19) をあげている。

いずれにせよ，かれらが指据しているよらに， $Y_{\text {ATP }}=$ 10.5 を常数 (biological constant) と考光て，これによ って代謝経路を推論したり，ATP の収象を这算したり

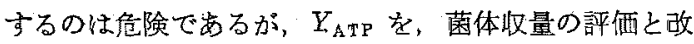
善のための指標とすることは，きわめて有用と考えられ 
る.

そこで，今回の結果（第 3 图）をみると，6 時間目あ たりからの $Y_{\mathrm{ATP}}$ (diff.) の急落は，ひ之つに估比增殖率 の低下自体を，すうひとつには，それに苚位菌体量当り の代謝速度の低下がついていけないことを反映している すのとる解される。 また， $Y_{\text {ATP }}$ (diff.)=10 付近のプラ 卜一快，単位菌体量当りの代謝速度の低下が，比增殖率 の低下に追いついてくる過程の反映として説明できるか もしれない。

㬰駼結果のところで述べたよらに， $Y_{\mathrm{ATP}}$ (diff.) $=10$ 付近のプラトーは, 現象としては，菌体量の增加とアル カリ消教量の增加が，ともに封間比対して直線的である ことの反映にほかならないが，実は增殖曲線が，時間に 対して直線的になること自体が，はなは㥓妙な現象で ある、一般に、このようなタイプの增殖曲線 (arithmetic linear growth) は，溶解度の小さい物質の共給が，增 殖の律速段階となっていることによると考光られて持 り，その例として，酸素の供給速度（培地中への溶解速 度）が律速段階になる場合があげられている(18)。しか し，木モ乳酸発こうを行なっているS. cremorisに，こ れをあてはめるのは無理であり，直線的增殖の機作は， いまのところ不明という伍かない。

直線部分を出はずれて以後の比增殖率の急落（したが

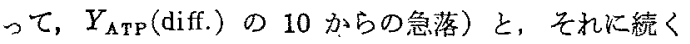
增殖停止の原因としては，(1) 栄養分の不足，(2) 阻害性 物質の蓄積，(3) 物理的な限界—-M-concentration ${ }^{(15)}$ が考克られる。

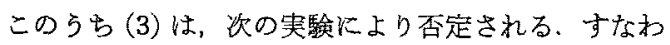
ち， $\mathrm{NH}_{4} \mathrm{OH}$ を中和郕と乙て培養し，菌体濃度が 2.5 $\mathrm{mg} / \mathrm{ml}$ 程度になったとき遠心分離し，乳楉を妨いた新 鮮培地で洗浄後，新鮮培地飞 $4 \mathrm{mg} / \mathrm{ml}$ 程度の漲度（1 回の培養で汪漂限界のところ) で再浮遊させ, 定 $\mathrm{pH}$ 培 荃をつづけると，わずかな lag ののら，急激にアルカ りの消費と增殖が起こり，菌体濃度は $8 \mathrm{mg} / \mathrm{ml}$ ，すなか ๖ 1 回の培着で頭打るになる值の約 2 倍に達する.

したがって增殖の制限は，增殖が止った時点でな和か， なりの糖が残っていることからみて，何か糖以外の培地 成分の不足か，阻害物質の蓄積によるとみるべきである 3 .

微生物が，その増殖の過程で，自己に対して阻害的な 未知の物筫を生産する現象は，広く認められている(16). Rogers and Wittier(1)は， pH を調節したS. lactisの

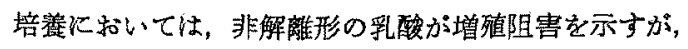
そのほか炕も未知の阻害因子が存在するとのべた，その 上らな因子のひとつとして，Gilliland and Speck(17) は 乳酸球菌の混合培養系で D-ワイシンをあげている。

私達も，培地中心乳酸以外の堌殖阻害因子が蓄積され ることを示唆する結果を得て和り，現在との本体につい て検討中である。

$$
\text { 要約 }
$$

乳酸菌の実験公的な定 $\mathrm{pH}$ 培着に便利な, 簡単な $\mathrm{pH}$ スタットを組久立て，乳糖 $5 \%$ を㞸素源とする培地で， Streptococcus cremoris を $\mathrm{pH}$ 6.0〜6.2 で培盖した. 中和剤としては，Peebles (4) らの指摘ど括り， $\mathrm{NH}_{4} \mathrm{OH}$ がすぐれていた。

增殖が停止した時点で，菌瀑度は乾懆菌体量で 4.2 $\mathrm{mg} / \mathrm{ml}$ ，生菌数で $3.7 \times 10^{9} / \mathrm{ml}$ (通常の脱脂乳培楸の約 7 倍）に達した，酸の生成性，堌殖停止後む糖を全部消 費さるまで続いた，糖を全部消費した時点では， $Y_{\text {ATP }}$ は約 9 であったが，培盖初期には 15〜16 といら高い值 がみとめられた． $Y_{\text {ATP }}$ とょって，菌体収量を評価する ことの有用性について論じた。

ガスクロマトグラフィーに上る揮発酸の分析をしてい ただいた当場生珪部小林剛技官，電気関係の工作にあた って打世話になった同部三橋俊彦技官に感謝します。

(1) L.A. Rogers and E. O. Wittier : J. Bacteriol., 16, 211 (1928).

(2) G.T. Lloyd: Dairy Sci. Abstr., 33, 411 (1971).

（3）矢野信礼，森地敏栓，入江良三郎，見坊 寛： 费化，34，1046 (1960).

(4) M.M. Peebles, S.E. Gilliland and M. L. Speck: Appl. Microbiol., 17, 805 (1969).

(5) H. J. Hohorst : Biochem. Z., 328, 509(1957).

(6) N. Nelson: J. Biol. Chem., 153, 375(1944).

(7) T. Bauchop and S.R. Elsden.: J. Gen. Microbiol., 23, 457 (1960).

(8) J.C. Senez: Bacteriol. Rev., 26, 95 (1962).

(9) W. J. Payne : Ann. Rev. Microbiol., 24, 17 (1970).

(10) H.H. Moustafa and E.B. Collins: J. Bacteriol., 96, 117 (1968).

(11) I.C. Gunsalus and C.W. Shuster: "The Bacteria,"Vol. II, ed. by I.C. Gunsalus and R.Y. Stanier, Academic Press Inc., New York, N. Y., 1961, p. 45.

(12） A. L. Lehninger：藤木大三郎，大森 彬，竹 
田真敏, 堀内健太郎共訳 “生命と土ネルギーの 科学”, 第 2 硕, 化学同人, 1971, p. 120 .

(13) W.P. Hempfling, S.E. Meinzer and P.J. Van Demark : Bacteriol Proc., 1969, 143 [文献 (9)より引用了.

(14) A.H. Stouthamer and C. Bettenhaussen : Biochim. Biophys. Acta, 301, 53 (1973).

(15) O. Bail : Zeitschr. Immun. Forsh., 60, 1 (1929) [T. Yanagita: Ann. Rept. of the Inst. Food. Microbiol., Chiba Univ, 2, 30 (1958) 上り拥了。

（16）中山大樹：農化，33，133 (1959).

(17) S.E. Gilliland and M. L. Speck : J. Dairy Sci., 51, 1573 (1968).

（18）丸山洋一：“微生物生理学”，植村定治郎, 福見 秀婎，楖田友道編，朝會莘店，1960，p. 146 。

(19) D.W. Tempest, D. Herbert and P.J. Phipps : "Microbial Physiology and Continuous Culture," ed. by E.O. Powell, C.G.T. Evans, R. E. Strange and D. W. Tempest, Her Majesty's Stationary Office, London, 1967, p. 240 [文献 (14) より引用].

(20) H.Dirar and E.B. Collins : J.Gen. Microbiol., 73, 233 (1972).

(21) H. Dirar and E.B. Collins : ibid., 78, 211 (1973).

(22) W. De Vries, W.M.C. Kapteijn, E.G. Van Der Beek and A.H. Stouthamer : ibid., 63, 333 (1970). 